\title{
MODEL PEMBELAJARAN DIRECT INTRUCTION DAN MODEL PEMBELAJARAN TGT TEAMS GAMES TOURNAMENT TERHADAP PENINGKATAN KEMAMPUAN KETERAMPILAN LAY-UP SHOOT DALAM PERMAINAN BOLA BASKET PADA SISWA KELAS XI SMK PASUNDAN 1 CIANJUR
}

\author{
Hendra Saputra \\ Pendidikan Jasmani Kesehatan dan Rekreasi \\ Fakultas Keguruan dan Ilmu Pendidikan, Universitas Suryakancana \\ dihosaputra@gmail.com
}

\begin{tabular}{l}
\hline Info Artikel \\
\hline Sejarah Artikel: \\
Diterima Oktober 2018 \\
Disetujui November 2018 \\
Dipublikasikan Desember \\
2018
\end{tabular}

Keyword:

TGF

Pembelajaraan

\section{Abstrak}

Penelitian ini berjudul. "Model Pembelajaran Direct Intruction dan Model Pembelajaran TGT Teams Games Tournament Terhadap Peningkatan Kemampuan Keterampilan Lay-Up Shoot dalam Permainan Bola Basket Pada Siswa Kelas XI SMK Pasundan 1 Cianjur".. Sampel yang dijadikan objek penelitian ini adalah siswa SMK Pasundan 1 Cianjur yang berjumlah 30 orang. Sedangkan untuk pembagian kelompok menggunakan teknik total sampling. Penelitian dilaksanakan selama enam minggu dengan latihan sebanyak 16 kali dan ditambah dua kali pertemuan untuk melaksanakan tes awal dan tes akhir. Instrumen penelitian yang digunakan berupa tes melakukan teknik lay-up shoot. Dari pengolahan data diperoleh kesimpulan bahwa model pembelajaran Direct Instruction berpengaruh secara signifikan terhadap peningkatan kemampuan keterampilan lay-up shoot dengan dibuktikan penghitungan setatistik $t_{\text {hitung }}$ sebesar 11,06 dengan $t_{\text {tabel }}$ sebesar $1.76, \mathrm{dk}=($ $\mathrm{n}-1$ ) dan tarap signifikan $\alpha=0.05$, demikian pula dengan model pembelajatan TGT Teams Games Tournament berpengaruh secara signifikan terhadap peningkatan kemampuan keterampilan lay-up shoot dengan di buktikanhasil penghitungan statistik $t_{\text {hitung }}$ sebesar 13.32 dengan $t_{\text {tabel }}$ sebesar $1.76, \mathrm{dk}=(\mathrm{n}-1)$ dengan tarap siqnifikan $\alpha=0.05$. Kesimpulan selanjutnya terdapat perbedaan yang signifikan antara model pembelajaran Direct Intruction dan model pembelajaran TGT Teams Games Tournament terhadap peningkatan kemampuan keterampilan lay-up shoot dalam permainan bola basket pada siswa kelas XI SMK Pasundan 1 Cianjur.

\section{Abstrack}

This research is titled. "Direct Intruction Learning Model and TGT Teams Games Tournament Learning Model for Improving the Capability of Lay-Up Shoot Skills in Basketball Games for Class XI Students of SMK Pasundan 1 Cianjur". person. As for the division of groups using total sampling techniques. The study was conducted for six weeks with 16 exercises and was added to two meetings to carry out the initial test and the final test. The research instrument used was in the form of a test 
conducting lay-up shoot techniques. From the data processing, it can be concluded that the Direct Instruction learning model significantly influences the ability to shoot shoot lay-up skills with proven tcount statistic calculation of 11.06 with a table of $1.76, d k=(n-1)$ and the tarap is significant $\alpha=0.05$, thus Likewise, the TGT Teams Games Tournament learning model has a significant effect on improving the ability of shoot lay-up skills by proving the results of the tcount statistics calculation of 13.32 with a ttable of $1.76, d k=(n-1)$ with a significance level $\alpha=0.05$. The next conclusion is that there is a significant difference between the Direct Intruction learning model and the TGT Teams Games Tournament learning model to improve the ability to shoot lay-up skills in basketball in class XI students of Pasundan 1 Cianjur VOCATIONAL SCHOOL

\section{(C) 2018 Universitas Suryakancana}

\begin{tabular}{lr}
\hline Alamat korespondensi: & e-ISSN : 2721-7175 (online) \\
E-mail: & p-ISSN : 2089-2341 (cetak) \\
Adirahadian@unsur.ac.id &
\end{tabular}

\section{PENDAHULUAN}

Pendidikan jasmani pada dasarnya merupakan sebuah kegiatan pendidikan yang mana bertujuan untuk mencapai tujuan pendidikan melalui aktivitas fisik, tetapi juga mencakup aspek emosional, sosial, intelektual, dan moral anak serta dapat menerapkan pola hidup sehat. Di samping itu juga pendidikan jasmani harus diutamakan karena mempunyai tujuan yang penting dalam upaya meningkatkan pertumbuhan dan pengembangan jasmani pesertadidik.

Banyak orang menganggap, kurang penting mengikuti mata pelajaran pendidikan jasmani, dikarenakan belum mengerti peran dan fungsi pendidikan jasmani. Salah satu masalah utama dalam pendidikan jasmani adalah rendahnya kualitas pendidikan jasmani di sekolahsekolah. Hal itu disebabkan karena terbatasnya kemampuan guru pendidikan jasmani dan terbatasnya sumber-sumber yang digunakan untuk mendukung terlaksananya proses pendidikan jasmani.

Model pembelajaran sangat berpengaruh tehadap hasil belajar yang dicapai oleh siswa. Ada beberapa model pembelajaran yang bisa diterapkan pada siswa, salah satunya adalah model pembelajaran Direct Intruction dan TGT (Team Games Tournament) yang masingmasing mempunyai pengaruh yang berbeda terhadap hasil belajar. Pembelajaran langsung adalah sebuah model pembelajaran yang berpusat pada guru. Untuk meningkatkan penguasaan berbagai ketrampilan dan pengetahuan faktual yang dapat diajarkan secara 
18| Hendra Saputra

Model Pembelajaran Direct Intruction Dan Model Pembelajaran Tgt Teams Games Tournament

Terhadap Peningkatan Kemampuan Keterampilan Lay-Up Shoot Dalam Permainan Bola Basket Pada

Siswa Kelas Xi Smk Pasundan 1 Cianjur

lansung seperti konsep yang ada.

Sedangkan pembelajaran TGT (Team

Games Tournament) merupakan suatu tipe pembelajaran yang menekankan siswa belajar dalam kelompok heterogen yang beranggota 3 atau 5 orang. Kelompok heterogen meliputi tingkat kemampuan akademik, jenis kelamin, suku (ras), dan status sosial.

Model-model pembelajaran langsung dan Teams Games Tournament (TGT) ini sangat diperlukan dalam pembelajaran bola basket khususnya dalam teknik dasar keterampilan lay-up shoot. Sebab fakta fakta di lapangan Layup shoot merupakan cara menembak yang paling efektip untuk memasukan bola kekeranjang lawan setelah berhasil melakukan terobosan pertahanan lawan, pemain harus dapat menangkap dan menguasai bola dengan baik dan kemudian melakukan awalan dua langkah yang dilanjutkan dengan gerakan lompatan keatas mendekati ring. Aspek penting yang perlu diperhatikan saat melakukan awalan adalah dua irama melangkah, setelah menangkap/menguasai bola pemain harus mengkonsentrasikan diri untuk melompat kedepan pada awalan langkah pertama, kemudian melangkah (jarak yang normal) pada langkah ke dua dan dilanjutkan dengan gerakan meloncat keatas dan melayang mendekati ring.

Berdasarkan permasalahan di atas maka dapat di rumuskan masalah sebagai berikut:
1. Apakah model pembelajaran Direct Instruction dapat meningkatkan kemampuan keterampilan lay-up shoot dalam permainan bola basket pada siswa kelas XI di SMK Pasundan 1 Cianjur?

2. Apakah model pembelajaran TGT (Teams Games Tournament) dapat meningkatkan kemampuan keterampilan lay-up shoot dalam permainan bola basket pada siswa kelas XI di SMK Pasundan 1 Cianjur?

3. Manakah yang lebih baik antara model pembelajaran Direct Intruction dan TGT (Teams Games Tournament) terhadap peningkatan kemampuan keterampilan lay-up shoot dalam permainan bola basket pada siswa kelas XI di SMK Pasundan 1 Cianjur? Tujuan penelitian yang ingin dicapai oleh penulis adalah sebagai berikut :

1. Untuk mengetahui pengaruh model pembelajaran Direct Instruction terhadap meningkatkan kemampuan keterampilan lay-up shoot dalam permainan bola basket pada siswa kelas XI di SMK Pasundan 1 Cianjur?

2. Untuk mengetahui pengaruh model pembelajaran TGT (Teams Games Tournament) terhadap meningkatkan kemampuan keterampilan lay-up shoot dalam permainan bola basket pada siswa kelas XI di SMK Pasundan 1 Cianjur?

3. Untuk mengetahui apakah ada perbandingan yang signifikan dalam 
19| Hendra Saputra

Model Pembelajaran Direct Intruction Dan Model Pembelajaran Tgt Teams Games Tournament

Terhadap Peningkatan Kemampuan Keterampilan Lay-Up Shoot Dalam Permainan Bola Basket Pada

Siswa Kelas Xi Smk Pasundan 1 Cianjur

pembelajaran Direct Intruction dan

TGT (Teams Games Tournament)

terhadap peningkatkan kemampuan

keterampilan lay-up shoot dalam

permainan bola basket pada siswa

kelas XI di SMK Pasundan 1 Cianjur?

\section{B. TEORI}

\section{Model Pembelajaran}

Model pembelajaran mempunyai makna yang lebih luas dari pada strategi, metode atau prosedur pembelajaran. Istilah model pembelajaran mempunyai empat ciri khusus yang tidak dipunyai oleh strategi atau metode pembelajaran.

1. Rasional teoritis yang logis yang disusun oleh pendidik.

2. Tujuan pembelajaran yang akan dicapai.

3. Langkah-langkah mengajar yang perlukan agar model pembelajaran dapat di laksanakan secara optimal.

4. Lingkungan belajar yang diperlukan agar tujuan pembelajaran dapat dicapai.

\section{Pengertian Model}

Mengajar adalah perbuatan yang kompleks. Perbuatan yang kompleks dapat diterjemaahkan sebagai penggunaan secara integrativ sejumlah komponen yang terkandung dalam perbuatan mengajar itu untuk menyampaikan pesan pengajaran. Oleh karena itu dalam dunia pengajaran ada baiknya guru menggunakan suatu proto type dari suatu teori atau model.
Disebut model karena hanya garis besar atau pokok-pokok yang memerlukan pengembangan yang sangat situasional.

Dalam Rosdiani (2012:3) ada beberapa pengertian mengenai model dari berbagai ahli yakni sebagai berikut : Menurut William A. ScHrode; D.Voich (1974) mengemukakan : "model is a representation of reality intended to explain the behavior of some aspects of it". Jadi model adalah suatu gambaran dari pada kenyataan yang dimaksudkan untuk menerangkan prilaku dari pada apa yang digambarkan tersebut.

$$
\text { Stephen P. Robins }
$$
mengatakan: "models is a simplified representation of some real world phenomenon". Yang berarti model adalah suatu representasi dari fenomena dunia nyata yang disederhanakan.

Riley M.J (1981) mengemukakan: "models represent am abstraction of reality: they represent what things were like, what there are like what they could be like, or what they shold be like. Model are designed to clarify certain aspect of a problem or problem area: they are supposed to highlight certain important relationships and certain key interaction". Model adalah representasi dari suatu abstraksi realistis, model merupakan gambaran tentang senuatu, bagaimana hendaknya dan atau bagaimana adanay sesuatu itu. Model dirancang uintuk menjelaskan aspek-aspek suatu persoalan atau ruang lingkup persoalan, dana dapat 
20| Hendra Saputra

Model Pembelajaran Direct Intruction Dan Model Pembelajaran Tgt Teams Games Tournament Terhadap Peningkatan Kemampuan Keterampilan Lay-Up Shoot Dalam Permainan Bola Basket Pada Siswa Kelas Xi Smk Pasundan 1 Cianjur

menjelaskan pula hubungan-hubungan yang penting.

Sedangkan menurut Ellias $\mathrm{M}$. Adward (1979) mengemukakan bahwa : "A model is a representation of real of a planed system." Model sebagai suatu representasi dari suatu kenyataan system yang direncanakan. Menurtu Rosdiani (2012:4) sendiri ia mengatakan bahwa model adalah suatu gambaran tentang sesuatu yang dapat memperjelas berbagai kaitan diantara unsur-unsur yang ada. Pembelajaran sebagai suatu system yang memerlukan model yang dapat memberikan kejelasan hubungan diantara semua komponen, unsur atau elemen system tersebut.

\section{Hakekat Model Pembelajaran Direct Instruction}

Pengertian Model pembelajaran yang menggunakan pendekatan mengajar yang dapat membantu siswa mempelajari keterampilan dasar dan memperoleh pengetahuan langkah demi langkah adalah model pengajaran langsung (direct intruction).

Model pengajaran langsung (direct instruction) dilandasi oleh teori belajar perilaku yang berpandangan bahwa belajar bergantung pada pengalaman termasuk pemberian umpan balik. Satu penerapan teori perilaku dalam belajar adalah pemberian penguatan umpan balik kepada siswa dalam pembelajaran merupakan penguatan yang merupakan penerapan teori perilaku tersebut.

Menurut Arends (2008:295), "Pembelajaran langsung adalah sebuah model pembelajaran yang berpusat pada guru untuk meningkatkan penguasaan berbagai ketrampilan dan pengetahuan faktual yang dapat diajarkan secara lansung seperti konsep yang ada"

Menurut Lutan

(1988:419)

"Pembelajaran langsung adalah guru atau pelatih mengajarkan secara langsung teknik yang sebenarnya" Model pengajaran langsung memberikan kesempatan siswa belajar dengan mengamati secara selektif, mengingat dan menirukan apa yang dimodelkan gurunya. Oleh karena itu hal penting yang harus diperhatikan dalam menerapkan model pengajaran langsung adalah menghindari menyampaikan pengetahuan yang terlalu kompleks. Di samping itu, model pengajaran langsung mengutamakan pendekatan deklaratif dengan titik berat pada proses belajar konsep dan keterampilan motorik, sehingga menciptakan suasana pembelajaran yang lebih terstruktur.

Guru yang menggunakan model pengajaran langsung tersebut bertanggung jawab dalam mengidentifikasi tujuan pembelajaran, struktur materi, dan keterampilan dasar yang akan diajarkan. Kemudian menyampaikan pengetahuan kepada siswa memberikan pemodelan/demonstrasi, memberikan 
21| Hendra Saputra

Model Pembelajaran Direct Intruction Dan Model Pembelajaran Tgt Teams Games Tournament Terhadap Peningkatan Kemampuan Keterampilan Lay-Up Shoot Dalam Permainan Bola Basket Pada Siswa Kelas Xi Smk Pasundan 1 Cianjur

kesempatan pada siswa untuk berlatih menerapkan konsep/keterampilan yang telah dipelajari, dan memberikan umpan balik.

a. Karakteristik Model Pembelajaran Direct Intruction

Salah satu karakteristik dari suatu model pembelajaran adalah adanya sintaks/tahapan pembelajaran. Selain harus memperhatikan sintaks, guru yang akan menggunakan pengajaran langsung juga harus memperhatikan variabel-variabel lingkungan lain, yaitu fokus akademik, arahan dan kontrol guru, harapan yang tinggi untuk kemajuan siswa, waktu dan dampak dari pembelajaran.

Fokus akademik merupakan prioritas pemilihan tugas-tugas yang harus dilakukan siswa selama pembelajaran, aktivitas akademik harus ditekankan. Pengarahan dan kontrol guru terjadi ketika memilih tugas-tugas siswa dan melaksanakan pembelajaran, menentukan kelompok, berperan sebagai sumber belajar selama pembelajaran dan meminimalkan kegiatan non akademik. Kegiatan pembelajaran diarahkan pada pencapaian tujuan sehingga guru memiliki harapan yang tinggi terhadap tugas-tugas yang harus dilaksanakan oleh siswa.

$$
\text { Sintaks model pengajaran }
$$
langsung memiliki 5 tahapan, sebagai berikut:

1. Fase Orientasi Pada fase ini guru memberikan kerangka pelajaran dan 
Model Pembelajaran Direct Intruction Dan Model Pembelajaran Tgt Teams Games Tournament Terhadap Peningkatan Kemampuan Keterampilan Lay-Up Shoot Dalam Permainan Bola Basket Pada Siswa Kelas Xi Smk Pasundan 1 Cianjur

a. Guru memberikan penguatan terhadap respon siswa yang benar dan mengoreksi yang salah

4. Fase Latihan Terbimbing Pada fase ini, siswa diberi kesempatan untukberlatih konsep dan keterampilan serta menerapkan pengetahuan atau keterampilan tersebut ke situasi kehidupan nyata. Latihan terbimbing ini dapat digunakan guru untuk mengakses kemampuan siswa dalam melakukan tugas, mengecek apakah siswa telah berhasil melakukan tugas dengan baik atau tidak, serta memberikan umpan balik. Guru memonitor dan memberikan bimbingan jika perlu.

5. Fase Latihan Mandiri Siswa melakukan kegiatan latihan secara mandiri, dan guru memberikan umpan balik bagi keberhasilan siswa.

b. Kelebihan dan Kelemahan

Secara umum setiap model pembelajaran mempunyai kelebihankelebihan yang membuat model pembelajaran tersebut lebih baik digunakan dibanding dengan model pembelajaran yang lainnya. Tetapi selain mempunyai kelebihan-kelebihan pada setiap model pembelajaran juga ditemukan keterbatasan-keterbatasan yang merupakan kelemahannya. Model pengajaran langsung mempunyai beberapa kelebihan sebagai berikut:

a. Dalam model pengajaran langsung, guru mengendalikan isi materi dan urutan informasi yang diterima oleh siswa sehingga dapat mempertahankan fokus mengenai apa yang harus dicapai oleh siswa.

b. Merupakan cara yang paling efektif untuk mengajarkan konsep dan keterampilan-keterampilan kepada siswa yang berprestasi rendah sekalipun.

c. Model ini dapat digunakan untuk membangun model pembelajaran dalam bidang studi tertentu. Guru dapat menunjukan bagaimana suatu permasalahan dapat didekati, bagaimana informasi dianalisis, bagaimana suatu pengetahuan dihasilkan.

d. Model pengajaran langsung menekankan kegiatan mendengarkan (melalui ceramah) dan kegiatan mengamati (melalui demonstrasi), sehingga membantu siswa yang cocok belajar dengan cara-cara ini.

e. Model pengajaran langsung dapat memberikan tantangan untuk mempertimbangkan kesenjangan antara teori dan fakta.

f. Model pengajaran langsung dapat diterapkan secara efektif dalam kelas besar maupun kelas yang kecil.

g. Siswa dapat mengetahui tujuan-tujuan pembelajaran dengan jelas.

h. Waktu untuk berbagi kegiatan pembelajaran dapat dikontrol dengan ketat. 
Model Pembelajaran Direct Intruction Dan Model Pembelajaran Tgt Teams Games Tournament

Terhadap Peningkatan Kemampuan Keterampilan Lay-Up Shoot Dalam Permainan Bola Basket Pada

Siswa Kelas Xi Smk Pasundan 1 Cianjur

i. Dalam model ini terdapat penekanan pada pencapaian akademik.

j. Kinerja siswa dapat dipantau secara cermat.

k. Umpan balik bagi siswa berorientasi akademik.

1. Model pengajaran langsung dapat digunakan untuk menekankan butirbutir penting atau kesulitan-kesulitan yang mungkin dihadapi siswa.

m. Model pengajaran langsung dapat menjadi cara yang efektif untuk mengajarkan informasi dan pengetahuan faktual dan terstruktur.

$$
\text { Model pengajaran langsung }
$$

mempunyai beberapa kelemahan yaitu, (1)

Karena dalam model ini berpusat pada guru, maka kesuksesan pembelajaran bergantung pada guru. Jika guru kurang dalam persiapan, pengetahuan, kepercayaan diri, antusiasme maka siswa dapat menjadi bosan, teralihkan perhatiannya, dan pembelajaran akan terhambat. (2) Model pengajaran langsung sangat bergantung pada cara komunikasi guru. Jika guru tidak dapat berkomunikasi dengan baik maka akan menjadikan pembelajaran menjadi kurang baik pula. Jika materi yang disampaikan bersifat kompleks, rinci atau abstrak, model pembelajaran langsung tidak dapat memberikan kesempatan pada siswa untuk cukup memproses dan memahami informasi yang disampaikan. (3) Jika terlalu sering menggunakan model pengajaran langsung akan membuat beranggapan bahwa guru akan memberitahu siswa semua informasi yang perlu diketahui. Hal ini akan menghilangkan rasa tanggung jawab mengenai pembelajan siswa itu sendiri.

Demonstrasi sangat bergantung pada keterampilan pengamatan siswa. Kenyataannya, banyak siswa bukanlah pengamat yang baik sehingga sering melewatkan hal-hal penting yang seharusnya diketahui.

a. Strategi Pembelajaran Langsung (direct instruction)

1. Strategi pembelajaran langsung merupakan strategi yang kadar berpusat pada gurunya paling tinggi, dan paling sering digunakan. Pada strategi ini termasuk di dalamnya metodemetode ceramah, pertanyaan didaktik, pengajaran eksplisit, praktek dan latihan, serta demonstrasi.

2. Strategi pembelajaran langsung efektif digunakan untuk memperluas informasi atau mengembangkan keterampilan langkah demi langkah

\section{Hakekat Model Pembelajaran TGT}

\section{(Teams Games Tournament)}

a. Pengertian Teams Games

Tournaments

Model pembelajaran Teams

Games Tournament (TGT) adalah salah satu tipe atau model pembelajaran 
24 | Hendra Saputra

Model Pembelajaran Direct Intruction Dan Model Pembelajaran Tgt Teams Games Tournament Terhadap Peningkatan Kemampuan Keterampilan Lay-Up Shoot Dalam Permainan Bola Basket Pada Siswa Kelas Xi Smk Pasundan 1 Cianjur

kooperatif yang mudah diterapkan, melibatkan aktivitas seluruh siswa tanpa harus ada perbedaan status, melibatkan peran siswa sebagai tutor sebaya dan mengandung unsur permainan dan reinforcement. Aktivitas belajar dengan permainan yang dirancang dalam pembelajaran kooperatif model Teams Games Tournament (TGT) memungkinkan siswa dapat belajar lebih rileks disamping menumbuhkan tanggung jawab, kejujuran, kerja sama, persaingan sehat dan keterlibatan belajar.

Teams Games Turnament (TGT) merupakan jenis pembelajaran yang berkaitan dengan STAD (Student-TeamssAchivement-Division) dimana dalam pembelajaran ini siswa belajar dalam kelompok-kelompok kecil yang beranggotakan 4-5 orang yang mempunyai kemampuan dan latar belakang yang berbeda untuk mencapai ketuntasan belajar. Dalam Teams Games Turnament siswa memainkan permainan dengan anggota teams lain untuk memperoleh tambahan poin pada skor teams mereka. Permainan disusun dari pernyataanpernyataan yang relevan dengan pelajaran yang dirancang untuk mengetes pengetahuan yang diperoleh siswa dari penyampaian pelajaran di lapangan olahraga dan kegiatan-kegiatan kelompok.

TGT merupakan salah satu tipe pembelajaran koopratif yaitu pertandingan permaianan tim, siswa memainkan permainan dengan anggota-anggota tim lain untuk memperoleh tambahan poin pada skor tim mereka. Permaianan disusun atas pertanyaan-pertanyaan yang relevan dengan pelajaran yang dirancang untuk mengetahui pengetahuan yang diperoleh siswa dari penyampaian pelajaran di lapangan olahraga dan kegiatan-kegiatan kelompok.

Nyoman Sadu (2010: 29-30) menulis langkah-langkah model pembelajaran TGT dari 6 fase yaitu:

1. Menyampaikan tujuan dan motivasi siswa, dalam fase ini sebagai pendahuluan kegiatan pembelajaran guru menyampaikan tujuan pembelajaran yang ingin dicapai dan memotivasi siswa.

2. Menyajikan informasi, pada fase ini guru menyajikan informasi kepada siswa dengan demonstrasi atau bacaan.

3. Mengorganisasikan siswa ke dalam kelompok-kelompok belajar, guru membantu siswa dalam setiap kelompok agar melakukan kegiatan secara efesien.

4. Membimbing kelompok bekerja dan belajar

5. Fase evaluasi, pada fase ini merupakan ciri khas tipe ini dengan melaksanakan pertandingan permainan tim atau Teams Games Tournament (TGT), pada fase ini siswa diberikan kesempatan untuk mempresentasikan materi yang telah dipelajari lewat pertandingan 
Model Pembelajaran Direct Intruction Dan Model Pembelajaran Tgt Teams Games Tournament Terhadap Peningkatan Kemampuan Keterampilan Lay-Up Shoot Dalam Permainan Bola Basket Pada Siswa Kelas Xi Smk Pasundan 1 Cianjur

permainan tim dengan menjawab soal-soal yang tertulis pada kartu soal di lapangan turnamen.

6. Memberikan penghargaan, pada fase ini diberikan penghargaan kepada kelompok dan individu dengan skor terbaik. Pemberian skor ini dapat dilakukan dengan: 1) menetapkan skor dasar, 2) memberi skor kuis (tes individu) yang dilaksanakan setelah bekerja dalam kelompok, 3) menghitung skor peningkatan yang besarnya ditentukan berdasar skor yang diperoleh dalam pertandingan permainan tim di meja turnamen yang dikenakan kepada setiap siswa, 4) penghargaan kelompok diberikan berdasarkan rata-rata nilai peningkatan yang diperoleh masingmasing kelompok dengan memberikan predikat seperti baik, sangat baik, istimewa, sempurna.

\section{b. Tahap Pembelajaran (Presentasi Pelajaran) \\ Terdapat lima langkah utama} dalam pembelajaran kooperatif. Pelajaran dalam pembelajaran kooperatif dimulai dengan guru mengkomunikasikan tujuantujuan pembelajaran dan memotivasi siswa untuk belajar. Langkah ini diikuti dengan penyajian informasi, sering dalam bentuk teks bukan verbal atau dalam bentuk pertanyaan yang mengarah ke permainan bola basket untuk menggali pengetahuan awal siswa sambil menghubungkan pengalaman dengan sehari-hari siswa. Juga dalam penyajian materi pelajaran hal-hal yang perlu ditekankan adalah sebagai berikut:

1. Mengembangkan materi pembelajaran sesuai dengan apa yang akan dipelajari siswa dalam kehidupan.

2. Pembelajaran kooperatif menekankan belajar adalah memahami makna bukan hafalan.

3. Mengontrol pemahaman siswa sesering mungkin dengan mengajukan pertanyaan- pertanyaan.

4. Memberi penjelasan mengapa jawaban pertanyaan tersebut benar atau salah.

5. Beralih pada konsep lain jika siswa telah memahami pokok masalahnya.

Pada langkah selanjutnya siswa diorganisasi dalam kelompok-kelompok belajar.Langkah itu diikuti dengan langkah-langkah dimana siswa di bawah bimbingan guru bekerja bersama-sama untuk menyelesaikan tugas/LKS.Langkah terakhir dari pembelajaran kooperatif meliputi penyajian dari produk akhir kelompok atau mengevaluasi materi yang telah dipelajari siswa. Evaluasi dikerjakan secara mandiri untuk menunjukan apa yang telah siswa pelajari selama bekerja kelompok.

kelompok atau hasil kerja yang nilainya besar, sehingga berprestasi didalam kelompok

c. Turnamen 
26 | Hendra Saputra

Model Pembelajaran Direct Intruction Dan Model Pembelajaran Tgt Teams Games Tournament Terhadap Peningkatan Kemampuan Keterampilan Lay-Up Shoot Dalam Permainan Bola Basket Pada Siswa Kelas Xi Smk Pasundan 1 Cianjur

Setelah selesai satu pokok bahasan diadakan turnamen dengan langkahlangkah sebagai berikut:

1. Tahap Persiapan.

Dalam tahap persiapan, guru menyiapkan daptar siswa yang sudah siap untuk melaksanakan mengikuti turnamen

2. Pembentukan kelompok turnamen

Langkah-langkah pembentukan kelompok turnamen adalah sebagai berikut:

Mengambil tiga kelompok pembelajaran, anggota dalam kelompok pembelajaran dipilih atau direngking menurut tes terakhir. Dan tiga kelompok pengajaran ini dibuat kelompok turnamen. Kelompok turnamen pertama anggotanya adalah anggota renking satu pada kelompok pengajaran. Anggota kelompok turnamen yang kedua beranggotakan anggota renking dua dan seterusnya sehingga kalau kelompok pembelajaran anggotanya masing-masing 5 orang, maka dari 3 kelompok pembelajaran didapatkan 5 kelompok turnamen.

3. Pelaksanaan Turnamen

Guru menjelaskan langkahlangkah turnamen sebagai berikut:

a. Siswa melaksanakan games yang di beri waktu 15 menit dan siswa harus memasukan bola dengan gaya keterampilan lay-up shot sebanyak banyaknya kedalam ring.

b. Siswa harus seportif c. Jika siswa melanggar aturan memasukan bola tanpa lay-up shoot siswa diberi hukum fush up

4. Kuis (tes)

Setelah diadakan turnamen, siswa mendapatkan kuis, secara individual untuk mengetahui tingkat penguasaan pengetahuan secara individual. Dalam mengerjakan kuis siswa dalam kelompok tidak diperbolehkan saling membantu. Dengan demikian siswa sebagai individual bertanggung jawab untuk memahami materi pembelajaran.

\section{Hakikat Lay-up Shoot}

Menurut Dedy Sumiyarsono (2002 :35-36) tembakan lay up adalah jenis tembakan yang dilakukan sedekat mungkin dengan basket yang didahului dengan lompat-langkah-lompat. Tembakan lay up dapat dilakukan dengan didahului berlari, menggiring atau memotong kemudian berlari dan menuju ke arah ring basket. Dalam melakukan tembakan lay up sebaiknya dilatihkan terlebih dahulu, sebelum dilaksanakan pada saat bermain sesungguhnya. Hal tersebut dikarenakan tembakan lay up memerlukan langkah dua atau lompatlangkah-lompat, yang akan berakibat melakukan pelanggaran. Adapun pelaksanaannya sebagai berikut:

a. Saat menerima bola, lurus dalam keadaan melayang dengan lompatan pertama sejauh mungkin yang 
27| Hendra Saputra

Model Pembelajaran Direct Intruction Dan Model Pembelajaran Tgt Teams Games Tournament

Terhadap Peningkatan Kemampuan Keterampilan Lay-Up Shoot Dalam Permainan Bola Basket Pada

Siswa Kelas Xi Smk Pasundan 1 Cianjur

mempunyai manfaat untuk meninggalkan lawan yang menjaga.

b. Saat melangkah, dilakukan dengan langkah pendek yang berfungsi untuk mempertahankan keseimbangan badan dan memperoleh awalan pada lompatan berikutnya setinggi mungkin agar dapat mendekat pada basket.

c. Saat pelepasan bola, dilakukan dengan kekuatan kecil sebaiknya dipantulkan papan disekitar garis tegak pada petak kecil yang tergambar pada papan basket.

\section{PEMBAHASAN}

\section{Deskripsi data}

a. Hasil keterampilan latihan model pembelajaran direct intruction

Hasil keterampilan lay-up shoot kelompok yang diberi latihan model pembelajaran direct intruction untuk tes awal menunjukan rentang nilai 66 s.d 83 dengan nilai rata - rata sebesar 74,27 dan nilai simpangan bakunya sebesar 4,79 serta untuk test akhir menunjukan rentang nilai 77 s.d 91 dengan nilai rata - rata 80,93 dan nilai simpangan bakunya sebesar 4,17

b. Hasil keterampilan latihan model pembelajaran TGT team games tournament

Hasil keterampilan lay-up shoot kelompok yang diberi latihan model pembelajaran TGT team games tournament untuk tes awal menunjukan rentang nilai 66 s.d 79 dengan nilai rata - rata sebesar 73,6 dan nilai simpangan bakunya sebesar 3,94 serta untuk tes akhir menunjukan rentang nilai 80 s.d 94 dengan nilai rata - rata 83,73 dan nilai simpangan bakunya sebesar 4,45

Tabel 4.1

Rata -rata dan Simpangan Deviasi Hasil Melakukan Lay up Shoot Pada Kedua Kelompok Latihan

\begin{tabular}{|l|c|l|l|l|}
\hline \multirow{2}{*}{ Variabel } & \multicolumn{2}{|c|}{$\begin{array}{c}\text { Kelompok I } \\
\text { Latihan Direct } \\
\text { Intruction }\end{array}$} & $\begin{array}{r}\text { Kelompok II } \\
\text { Latihan TGT } \\
\text { (Teams } \\
\text { Games } \\
\text { Tournament })\end{array}$ \\
\cline { 2 - 5 } & Mean & SD & Mean & SD \\
\hline $\begin{array}{l}\text { Tes } \\
\text { Awal }\end{array}$ & 74,27 & 4,79 & 73,6 & 3,94 \\
\hline $\begin{array}{l}\text { Tes } \\
\text { Akhir }\end{array}$ & 80,93 & 4,17 & 83,73 & 4,45 \\
\hline
\end{tabular}

\section{Pengujian Persyaratan Analisis}

Sebelum dilakukan analisis data, perlu dilakukan pengujian persyaratan analisis. Pengujian persyaratan analisis yang dilakukan terdiri dari uji normalitas dan uji homogenitas.

a. Uji Normalitas

Sebelum dilakukan analisis data di uji distribusi kenormalannya dari data tes model pembelajaran Direct Instruction dan model pembelajaran TGT (Teams Games Tournament). Uji normalitas data dalam penelitian ini digunakan metode Lilliefors. Hasil uji normalitas data yang dilakukan terhadap hasil tes pada kelompok I dan kelompok II adalah sebagai berikut : 
28 | Hendra Saputra

Model Pembelajaran Direct Intruction Dan Model Pembelajaran Tgt Teams Games Tournament Terhadap Peningkatan Kemampuan Keterampilan Lay-Up Shoot Dalam Permainan Bola Basket Pada Siswa Kelas Xi Smk Pasundan 1 Cianjur

Tabel 4.2

Hasil Perhitungan Uji Normalitas

Data

\begin{tabular}{|c|c|c|c|c|c|}
\hline \multicolumn{2}{|c|}{ Kelompok } & \multicolumn{4}{|c|}{$\begin{array}{c}\text { L Hifalah sebagaiberikut }: \text { Kesimpulan } \\
\text { Tabel } 4.3\end{array}$} \\
\hline \multirow{2}{*}{$\begin{array}{c}\text { Kelompok I } \\
\text { Direct instruction }\end{array}$} & Tes Awal & 0,093 & \multicolumn{3}{|c|}{$\begin{array}{l}\text { 0Azail Perhitungan Uji } \\
\text { Homogenitas }\end{array}$} \\
\hline & Tes Akhir & 0,107 & 0,220 & \multicolumn{2}{|c|}{ Normal } \\
\hline \multirow{4}{*}{$\begin{array}{c}\text { Kelompok II } \\
\text { TGT (teams games } \\
\text { tournament) }\end{array}$} & \multirow[t]{2}{*}{ Tes Awal } & 0,1702 & $0,22 \theta$ & \multicolumn{2}{|c|}{$\mathrm{F}^{\text {Normal }}$} \\
\hline & & Kelomplok & Hitun & Tabe & \\
\hline & Tes Akhir & 0,0634 & $0,22 \$$ & \multicolumn{2}{|c|}{1 Normal } \\
\hline & & Kelomplok & & & \multirow{2}{*}{ Homogen } \\
\hline \multicolumn{2}{|c|}{ Berdasarkan hasil uji normalitas } & $\begin{array}{l}\text { Direct } \\
\text { intruction }\end{array}$ & 1,32 & 2,48 & \\
\hline \multicolumn{2}{|c|}{$\begin{array}{l}\text { yang dilakukan pada kelompok A } \\
\text { diperoleh nilai tes awal L hitung }=0,093 \\
\text { dan tes akhir L hitung }=0,107 \text {. Nilai } \\
\text { tersebut lebih kecil dari angka batas }\end{array}$} & $\begin{array}{l}\text { Kelompok } \\
\text { II } \\
\text { TGT } \\
\text { (teams } \\
\text { games } \\
\text { tournamen } \\
\text { t) }\end{array}$ & 0,78 & 2,48 & Homogen \\
\hline
\end{tabular}

penolakan pada taraf signifikan $\propto=0,05$

yaitu 0,220. Dengan demikian dapat disimpulkan bahwa data pada kelompok I berdistribusi normal. Sedangkan dari hasil uji normalitas yang dilakukan pada kelompok II diperoleh nilai tes awal $\mathrm{L}$ hitung $=0,1702$ dan tes akhir L hitung $=$ 0,0634 . Nilai tersebut juga lebih kecil dari angka batas penolakan pada taraf signifikan $\propto=0,05$ yaitu 0,220 . Dengan demikian dapat disimpulkan bahwa data pada kelompok II berdistribusi normal.

\section{b. Uji Homogenitas}

Uji homogenitas dimaksudkan untuk mengetahui kesamaan varians dari kedua kelompok. Jika kedua kelompok tersebut memiliki kesamaan varians, maka apabila nantinya kedua kelompok memiliki perbedaan, maka perbedaan tersebut disebabkan perbedaan rata-rata kemampuannya. Hasil uji homogenitas data antara kelompok I dan kelompok II

Berdasarkan data pada tabel di atas tentang uji homogenitas, maka : Ho ditermi jika F $(1-\alpha)(\mathrm{n} 1-1)<\mathrm{F}<\mathrm{F} 1 / 2 \alpha(\mathrm{n} 1-1, \mathrm{n} 2-$ 1) untuk taraf nyata $\propto=0,05$ dan $\mathrm{dk}$ pembilang $=\mathrm{n} 1-1 \mathrm{dan} \mathrm{dk}$ penyebutnya $=$ n2-1.

Hasil uji homogenitas yang dilakukan pada kelompok I diperoleh nilai F hitung 1,32 sedangkan kelompok II diperoleh $\mathrm{F}$ hitung $=0,78$ Ternyata kedua $\mathrm{F}$ hitung lebih kecil dari $\mathrm{F}$ tabel 0,05 $(14: 14)=2,48$ maka hipotesis tersebut diterima. Dengan demikian dapat disimpulkan bahwa kelompok I dan kelompok II memiliki varians yang homogen.

\section{Pengujian Hipotesis}


29| Hendra Saputra

Model Pembelajaran Direct Intruction Dan Model Pembelajaran Tgt Teams Games Tournament Terhadap Peningkatan Kemampuan Keterampilan Lay-Up Shoot Dalam Permainan Bola Basket Pada Siswa Kelas Xi Smk Pasundan 1 Cianjur

Pengujian terhadap hipotesis pertama dan kedua menggunakan teknik analisis uji-t satu arah dan untuk pengujian hipotesis ketiga menggunakan teknik analisis uji-t perbedaan dua rata-rata.

Tabel 4.4

Rangkuman Hasil Penghitungan

Uji-t Terhadap Hasil model pembelajaran direct instruction dan TGT (Teams Games

Tournament)

Traf Signifikan $\infty 0.05$

\begin{tabular}{|c|c|c|c|c|}
\hline $\begin{array}{c}\text { Kelompok } \\
\text { yang } \\
\text { dibandingkan }\end{array}$ & $\begin{array}{c}\text { Dk } \\
(\mathrm{n}-\end{array}$ & $\mathrm{t}_{\mathrm{h}}$ & $\mathrm{t}_{\mathrm{t}}$ & Kesimpilan \\
\hline $\begin{array}{c}\text { Tes Awal-Tes } \\
\text { Akhir } \\
\text { Kelompok I }\end{array}$ & 14 & 11,06 & 1,76 & Signifikan \\
\hline $\begin{array}{c}\text { Tes Awal-Tes } \\
\text { Akhir } \\
\text { Kelompok II }\end{array}$ & 14 & 13,32 & 1,76 & Signifikan \\
\hline $\begin{array}{c}\text { Tes Akhir-Tes } \\
\text { Akhir } \\
\text { Kel I - Kel II }\end{array}$ & 28 & 1,86 & 1,70 & Signifikan \\
\hline
\end{tabular}

a). Hipotesis Pertama

$\mathrm{H}_{\mathrm{o}}: \mu 1<\mu 2$

$\mathrm{H}_{\mathrm{a}}: \mu 1>\mu 2$

Artinya :

$\mathrm{H}_{\mathrm{o}}$ : Tidak ada pengaruh yang signifikan dalam model pembelajaran direct instruction. Apabila nilai $t_{h}$ (t-hitung) lebih kecil dari pada nilai $t_{t}$ (t-tabel).
$\mathrm{H}_{\mathrm{a}}$ : Ada pengaruh yang signifikan dalam model pembelajaran direct instruction. Apabila nilai $\mathrm{t}_{\mathrm{h}}(\mathrm{t}-$ hitung) lebih besar dari pada nilai $\mathrm{t}_{\mathrm{t}}(\mathrm{t}$-tabel).

Pada tabel diatas tampak bahwa harga $t_{h}$ ternyata lebih besar dari harga $t_{t}$ $\left(t_{h}=11,06>t_{t}=1,76\right)$ dengan demikian Ho ditolak dan Ha diterima. Oleh karena itu hipotesis alternatif yang berbunyi : "Ada pengaruh yang signifikan dalam model pembelajaran direct instruction terhadap meningkatkan kemampuan keterampilan lay up shoot dalam permainan bola basket, pada siswa kelas XI SMK Pasundan 1 Cianjur apabila nilai t-hitung $\left(\mathrm{t}_{\mathrm{h}}\right.$ ) lebih besar dari pada nilai ttabel", diterima pada taraf signifikan $\infty$ 0.05 dan teruji kebenarannya dalam penelitian ini.

b). Hipotesis Kedua

Ho $\quad: \mu_{1}<\mu_{2}$

На $: \mu_{1}>\mu_{2}$

Artinya :

$\mathrm{H}_{\mathrm{o}}$ : Tidak ada pengaruh yang signifikan dalam model pembelajaran TGT (Teams

Games Tournament). Apabila nilai $t_{h}$ (t-hitung) lebih kecil dari pada nilai $\mathrm{t}_{\mathrm{t}}(\mathrm{t}$-tabel $)$

$\mathrm{H}_{\mathrm{a}}$ : Ada pengaruh yang signifikan dalam model pembelajaran $T G T$ (Teams Games Tournament). Apabila nilai $\mathrm{t}_{\mathrm{h}}$ (t-hitung) lebih kecil dari pada nilai $\mathrm{t}_{\mathrm{t}}(\mathrm{t}-\mathrm{tabel})$ 
30| Hendra Saputra

Model Pembelajaran Direct Intruction Dan Model Pembelajaran Tgt Teams Games Tournament Terhadap Peningkatan Kemampuan Keterampilan Lay-Up Shoot Dalam Permainan Bola Basket Pada Siswa Kelas Xi Smk Pasundan 1 Cianjur

Pada tabel diatas tampak bahwa harga $t_{h}$ ternyata lebih besar dari harga $t_{t}($ $\left.t_{h}=13,32>t_{t}=1,76\right)$ dengan demikian Ho ditolak dan Ha diterima. Oleh karena itu hipotesis alternatif yang berbunyi : "Ada pengaruh yang signifikan signifikan dalam model pembelajaran TGT (Teams Games Tournament), terhadap meningkatkan kemampuan keterampilan lay up shoot dalam permainan bola basket, apabila nilai t-hitung $\left(t_{h}\right)$ lebih besar daripada nilai ttabel $\left(t_{t}\right)$ ", diterima pada taraf signifikan $\infty$ 0.05 dan teruji kebenarannya dalam penelitian ini.

c). Hipotesis Ketiga

$\begin{array}{ll}\text { Ho } & : \overline{\mathrm{X}}_{1}<\overline{\mathrm{X}_{2}} \\ \text { Ha } & : \overline{\mathrm{X}}_{1}>\overline{\mathrm{X}_{2}}\end{array}$

Artinya :

$\mathrm{H}_{\mathrm{o}}$ : latihan model pembelajaran direct instruction tidak ada perbedaan pengaruh dengan TGT (Teams Games Tournament) terhadap peningkatkan kemampuan keterampilan lay-up shoot dalam permainan bola basket, jika nilai $\mathrm{t}_{\mathrm{h}}$ (t-hitung) lebih kecil pada nilai $t_{t}(t-$ tabel $)$

$\mathrm{H}_{\mathrm{a}}$ : latihan model pembelajaran TGT (Teams Games Tournament) lebih baik dari pada latihan model pembelajaran direct instruction terhadap peningkatkan kemampuan keterampilan lay up shoot dalam permainan bola basket, jika nilai $\mathrm{t}_{\mathrm{h}}$ (t-hitung) lebih besar dari pada nilai $\mathrm{t}_{\mathrm{t}}(\mathrm{t}$-tabel)

Pada tabel diatas tampak bahwa harga $t_{h}$ ternyata lebih besar dari harga $t_{t}($ $\left.t_{h}=1,86<t_{t}=1,70\right)$ dengan demikian Ho ditolak dan Ha diterima. Oleh karena itu hipotesis alternatif yang berbunyi : "Latihan model pembelajaran TGT (Teams Games Tournament) lebih baik dari pada latihan model pembelajaran direct instruction terhadap peningkatkan kemampuan keterampilan lay up shoot dalam permainan bola basket di SMK Pasundan 1 Cianjur apabila nilai t-hitung $\left(\mathrm{t}_{\mathrm{h}}\right)$ lebih besar dari pada nilai t-tabel $\left(\mathrm{t}_{\mathrm{t}}\right)$ ", diterima pada taraf signifikan $\infty 0.05$ dan teruji kebenarannya dalam penelitian ini.

\section{SIMPULAN}

Dari hasil penelitian dan analisis data yang telah dilakukan tentang "model pembelajaran direct intruction dan model pembelajaran TGT (Teams Games Tournament) terhadap peningkatkan kemampuan keterampilan lay-up shoot dalam permainan bola basket pada siswa kelas XI di SMK Pasundan 1 Cianjur", Maka dapat diambil beberapa kesimpulan sebagai berikut :

1. Ada pengaruh yang signifikan dalam model pembelajaran direct instruction terhadap peningkatkan kemampuan keterampilan lay up shoot dalam permainan bola 
31 | Hendra Saputra

Model Pembelajaran Direct Intruction Dan Model Pembelajaran Tgt Teams Games Tournament Terhadap Peningkatan Kemampuan Keterampilan Lay-Up Shoot Dalam Permainan Bola Basket Pada Siswa Kelas Xi Smk Pasundan 1 Cianjur

basket, pada siswa kelas XI SMK Pasundan 1 Cianjur

2. Ada pengaruh yang signifikan dalam model pembelajaran TGT (teams games tournament) terhadap peningkatkan kemampuan keterampilan lay up shoot dalam permainan bola basket

3. Model pembelajaran TGT (Teams Games Tournament) lebih baik dari pada latihan model pembelajaran direct instruction terhadap peningkatkan kemampuan keterampilan lay up shoot dalam permainan bola basket di SMK Pasundan 1 Cianjur.

\section{DAFTAR PUSTAKA}

Arikunto, Suharsimi.2002. Prosedur

Penelitian Suatau Pendekatan

Praktek.Rineka Cipta:Jakarta.

Arikunto, Suharsimi.2010. Prosedur Penelitian Suatau Pendekatan Praktek. Jakarta:Rineka Cipta.

Hartono,M.Bhakti.2012.Diktatpermainan

Bola Basket. Cianjur :Universitas Suryakancana
Harsono. 1982. Choaching dan aspekaspek psikologi dalam coaching.

Jakarta: CV. Tambak Kusuma.

Juliantine,Tite dkk.2011. Model-Model Pembelajaran Pendidikan Jasmani. Bandung :UniversitasPendidikan Indonesia. Oliver.Jon.2009. Dasar-Dasar Bola Basket. Bandung :Pakaraya.

Richard, A. Scmidt dan Rusli, Lutan. (1988). Motor Control and leaning (Belajar Keterampilan Motorik Pengantar Teori dan Metode, Jakarta: Departemen Pendidikan dan Kebudayaan Direktorat Jendral Pendidikan Tinggi.

Rosdiani, Dini.2012. Model-Pembelajaran Langsung Dalam Pendidikan Jasmani

Dan Kesehatan. Bandung:Alfabeta. Slavin,Robert E. Cooperative Learning Teori, Riset, dan Praktik. Bandung :Nusa Media.2009.

Sugiono. Metode Penelitian Pendidikan Pendekatan Kuantitatif, Kualitatif Dan R\&D. Bandung:Alfabeta.2008. Winataputra,Udin S.2007. Teori Belajar Dan Pembelajaran.

Jakarta:Universitas

Terbuka 